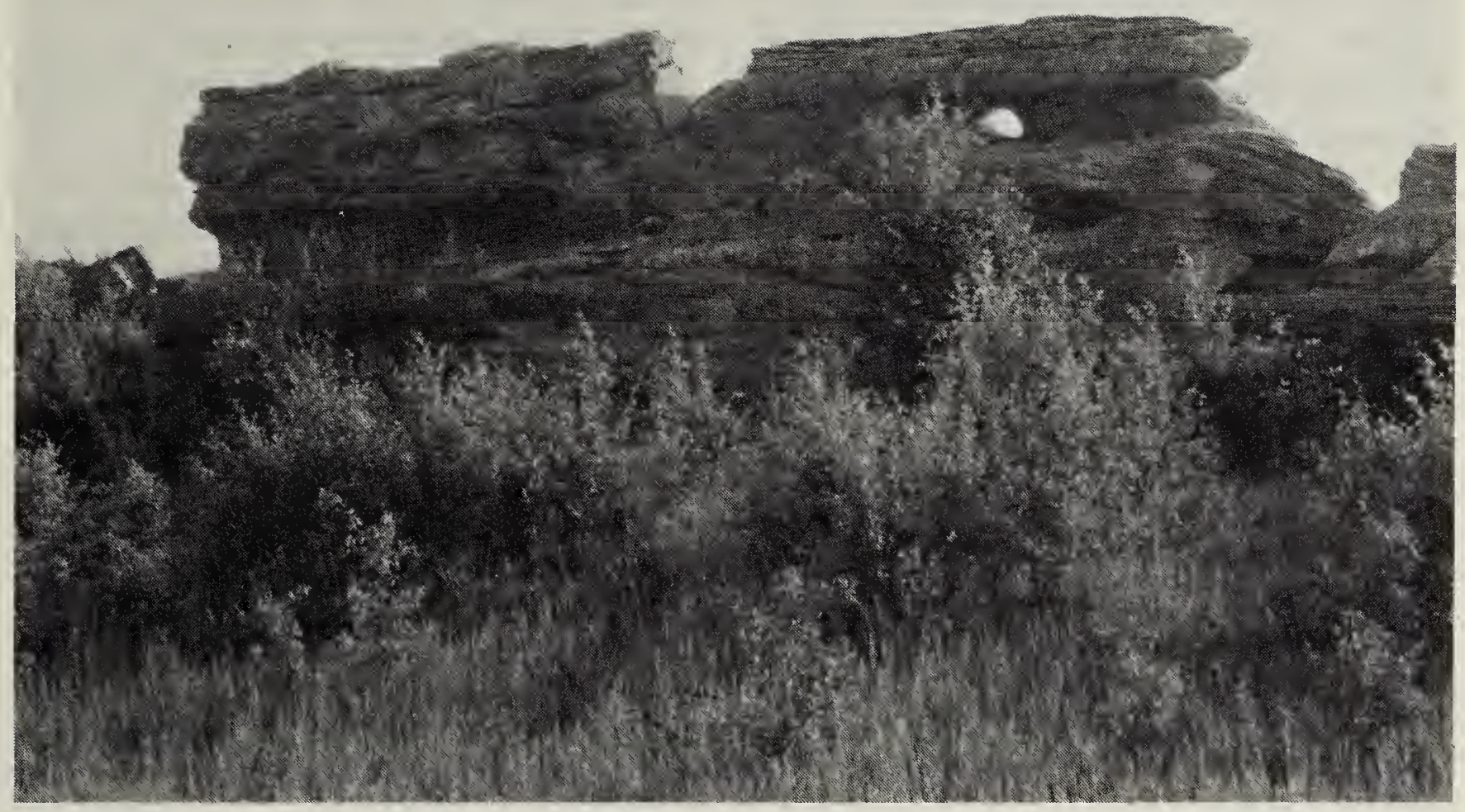

\section{A SOURIS RIVER BIRDING HOTSPOT}

The Souris River in southeastern Saskatchewan is known for its interesting birds. One particular section of the river valley that is readily accessible to bird watchers begins south of the Shand Power Station outside Estevan. Here a gravel road winds east along the valley passing by eroded valley banks, through brushy areas, beside the heavily treed riverbank, hay fields, hoodoolike formations and through native prairie in the Coalfields PFRA Pasture.

I have made several trips through this area, and on each trip I have found one or more rare Saskatchewan species such as Indigo Bunting, Field Sparrow or Yellow-throated Vireo. On the eroded valley slopes I have found a Rock Wren with Rufous-sided Towhees and Lark Sparrows singing from nearby bushes. Northern Rough-winged
Swallows and Common Nighthawks may be seen overhead, and Golden Eagles have occurred in the area. Willow Flycatchers and Eastern Bluebirds have occurred along the valley, and a trip through the heavily treed Roche Percee Campground will yield Black-and-white Warblers, Ovenbirds, Veerys and American Redstarts. White-breasted Nuthatches, Belted Kingfishers, and Black-billed Cuckoos may be heard along the river. One might also find Eastern Wood-Pewees or Blue Jays here. In the open prairie of Coalfields Pasture, a short climb out of the valley, Upland Sandpipers, Baird's Sparrows, Chestnust-collared Longspurs, Short-eared Owls, Sprague's Pipits, Le Conte's Sparrows, Grasshopper Sparrows and Ferruginous Hawks may be found.

On one trip to the valley with Boyd Metzler, we decided to explore a "hot" spot that Al Smith found north of Roche Percee among rock outcroppings. While eating lunch on 
some hoodoo-like rock formations, we were dazzled by a male Indigo Bunting, Lazuli Bunting, Field Sparrow, Lark Sparrow and Say's Phoebe - all demonstrating territorial behaviour. It was one of the most interesting lunches I have ever had.

These species may not be found on every trip, but most can be found with a bit of hiking and exploring along the valley. In addition to the bird life, this section of the valley has interesting geological formations and numerous wildflowers. A trip along this unique valley is always rewarding.

- John Pollock, Box 353, Whitewood, SK. SOG 5 CO

\section{NOTES FROM BIRCH HILLS}

I have three informational items.

First, I live on a quarter section of land where the farmyard is surrounded by trees. We don't have cats, consequently songbirds are not preyed upon by what has been called a privileged predator. One mid-morning during the first week of July I was drawn outside by the highly agitated voices of the three pairs of robins that nest here. When I got to where I could observe the cause of the noise, I was just in time to see the robins, soon joined by a pair of Eastern Kingbirds, mobbing a Big Brown Bat. The bat was making a valiant effort to evade the harassment, but the birds were extremely ferocious in their attacks and the bat was forced to fly into the adjacent aspens after which the birds returned to their respective territories.

I'd never seen such extreme behaviour from robins or kingbirds, not even when a Long-tailed Weasel skipped across the yard one week later. During the chase, the bat was making screeching sounds while the birds seemed to be cooperating in the attack. Two would fly alongside while a third one would fly close enough above the bat to peck at its head. Even though the wingspan of the bat appeared to be equal to the robins, there was no way he could avoid his tormentors.

The second item has to do with a different type of predation. Our farm water supply comes from a large dugout around which my wife and I have erected some bluebird/Tree Swallow nest boxes. One of these houses had seemed to be a death trap for the swallows and I was on the verge of destroying the box when, in late June, I happened to be going to the dugout to check on the shrubs we've planted there. I heard a commotion originating in the "killer" birdhouse and when I approached it, out flew a House Sparrow. When I opened the house, a Tree Swallow was in its death throes on the floor. The back of its head was bloody and its feathers in disarray.

Discussions with another birder suggested that House Sparrows have been suspected as killers in other areas of the province, particularly where nest box routes had been established. In addition, in all the instances of finding swallows dead in this particular house, there was no evidence of the bodies having been used as food. They seemed to have been killed simply because they were there. The solution to this problem became evident when I measured the entry hole and found it to be 1.5 inches. Subsequently, I cut out a piece of wood with a hole of 1.25 inches and nailed it over the "killer box" entry. Since then, though Tree Swallows have been observed going in and out of the box, no more dead swallows have been found.

Thirdly, on July 22, my wife and I were travelling from beach to beach 